\title{
Studies on electrochemical dissolution of sintered molybdenum discs as a potential method for targets dissolution in ${ }^{99 \mathrm{~m}} \mathrm{Tc}$ production
}

\author{
Izabela Cieszykowska $^{1}$ (D) Katarzyna Jerzyk $^{1}$ (D) $\cdot$ Małgorzata Żółtowska $^{1}$ (D) $\cdot$ Tomasz Janiak $^{1}$ (D) $\cdot$ Grażyna Birnbaum $^{1}$ (D)
}

Received: 18 October 2021 / Accepted: 7 December 2021 / Published online: 20 December 2021

(c) The Author(s) 2021

\begin{abstract}
Electrochemical dissolution of pressed into discs and sintered metallic molybdenum powder with the mass of $712 \pm 10 \mathrm{mg}$ $(n=15)$ in potassium hydroxide solution was studied in detail. The technique was considered to apply for dissolution of irradiated ${ }^{100}$ Mo target in the ${ }^{99 \mathrm{~m}} \mathrm{Tc}$ production. The effect of various parameters, e.g., the concentration of the electrolyte solution, temperature, current density, and surface area of the platinum cathode, was investigated. The shortest time for total dissolution of molybdenum target was $70 \mathrm{~min}$. This result was achieved using an electrolyte solution of $5 \mathrm{M} \mathrm{KOH}$, temperature $55^{\circ} \mathrm{C}$ and the current density of $365 \mathrm{~mA} / \mathrm{cm}^{2}$.
\end{abstract}

Keywords Electrochemical oxidation $\cdot$ Anodic dissolution $\cdot$ Cyclotron $\cdot$ Molybdenum $\cdot$ Technetium-99 m

\section{Introduction}

Technetium-99 $\mathrm{m}\left({ }^{99 \mathrm{~m}} \mathrm{Tc}\right)$ is widely used in nuclear medicine. It is often called the workhorse of modern medical imaging. Medical diagnostic imaging using ${ }^{99 \mathrm{~m}}$ Tc accounts for approximately $85 \%$ of all nuclear medicine procedures, representing around 30-40 million examinations worldwide every year [1]. Up to date, it is obtained in the decay of molybdenum-99 $\left({ }^{99} \mathrm{Mo}\right)$, isolated from uranium-235 $\left({ }^{235} \mathrm{U}\right)$ fission after its irradiation in a nuclear reactor [2, 3]. However, due to the aging of nuclear reactors involved in the production of ${ }^{99} \mathrm{Mo}$, their extended maintenance periods, and, in certain cases, also shut down, the supply of ${ }^{99} \mathrm{Mo}$ might be uncertain [1, 4-6]. To prevent the shortages in ${ }^{99 \mathrm{~m}} \mathrm{Tc}$ availability, alternative technologies for its production have been suggested [3,7-28]. Out of these, there are two which seem to be most interesting: the direct production of ${ }^{99 \mathrm{~m}} \mathrm{Tc}$ through the bombardment of ${ }^{100} \mathrm{Mo}$ with protons in a cyclotron in the nuclear reaction ${ }^{100} \mathrm{Mo}(\mathrm{p}, 2 \mathrm{n}){ }^{99 \mathrm{~m}} \mathrm{Tc}$ [11-20] and the photonuclear reaction with photon source from bremsstrahlung ${ }^{100} \mathrm{Mo}(\gamma, \mathrm{n}){ }^{99} \mathrm{Mo}$ [21-28]. In both methods, metallic molybdenum of high purity $(>99 \%)$ enriched in ${ }^{100} \mathrm{Mo}$ as a target material is recommended [11, 15, 16, 29].

Izabela Cieszykowska

izabela.cieszykowska@polatom.pl

1 National Centre for Nuclear Research, Radioisotope Centre POLATOM, Andrzej Sołtan 7, 05-400 Otwock, Poland
It's worth noting that targets made of pressed molybdenum oxide or molybdenum carbide were also used in the production of ${ }^{99 \mathrm{~m}}$ Tc $[11,18]$. Nevertheless, metallic molybdenum is preferred due to its high melting point, resistance to high temperatures generated by the bombardment of charged particles, and high thermal conductivity. Molybdenum enriched in ${ }^{100} \mathrm{Mo}$ in the form of metallic powder is available commercially (99.815\%, ISOFLEX, USA). However, the appropriate technique must be employed to prepare it in a durable target resistant to a high current beam. The approaches to prepare natural and enriched molybdenum targets included the use of foils [30], pressed and sintered powder [15, 16, 31], physical vapor deposition (PVD) [32], and electrophoretic deposition [33]. In our previous work, we demonstrated the manufacturing of a high-density ${ }^{100}$ Mo metallic target using pressing of molybdenum powder into pellets and their subsequent sintering in a reductive atmosphere [31].

For the processing of ${ }^{100} \mathrm{Mo}$, the irradiated target needs to be dissolved. Both the dissolution and the chemical separation of ${ }^{99 \mathrm{~m}} \mathrm{Tc}$ from the irradiated target material should be fast because of the relatively short half-life of ${ }^{99 \mathrm{~m}} \mathrm{Tc}(\sim 6 \mathrm{~h})$. Also, the chemical composition of solvent used for the target dissolution should be rather simple, preferably mono component, thus making further separation of ${ }^{99 \mathrm{~m}} \mathrm{Tc}$ from the excess of molybdenum feasible. There are few approaches to the dissolution of metal molybdenum. The most common and well-defined is alkaline dissolution by the oxidation of metallic molybdenum to molybdenum trioxide or molybdic 
acid (VI) with $30 \%$ or $50 \%$ hot hydrogen peroxide and then dissolving the resulting precipitate in either $\mathrm{NaOH}, \mathrm{KOH}$, or $\left(\mathrm{NH}_{4}\right)_{2} \mathrm{CO}_{3}$ solutions [16, 34-40]. That process led to the formation of sodium/potassium/ammonium molybdate, according to the following reactions (1)-(4) given with $\mathrm{NaOH}$ as an example:

$$
\begin{aligned}
& \mathrm{Mo}+3 \mathrm{H}_{2} \mathrm{O}_{2} \rightarrow \mathrm{MoO}_{3}+3 \mathrm{H}_{2} \mathrm{O} \\
& \mathrm{MoO}_{3}+2 \mathrm{NaOH} \rightarrow \mathrm{Na}_{2} \mathrm{MoO}_{4}+\mathrm{H}_{2} \mathrm{O}
\end{aligned}
$$

or

$\mathrm{Mo}+3 \mathrm{H}_{2} \mathrm{O}_{2} \rightarrow \mathrm{MoO}_{3}+3 \mathrm{H}_{2} \mathrm{O}$

$\mathrm{H}_{2} \mathrm{MoO}_{4}+2 \mathrm{NaOH} \rightarrow \mathrm{Na}_{2} \mathrm{MoO}_{4}+2 \mathrm{H}_{2} \mathrm{O}$

The time of molybdenum dissolution in $30 \%$ hydrogen peroxide depended on the physical form of Mo [34]. The 500-530 mg metal molybdenum foil and 720-760 mg metallic molybdenum powder pressed into disc dissolved within 3-5 min at $80{ }^{\circ} \mathrm{C}$ and within 2 min when the temperature was $90{ }^{\circ} \mathrm{C}$. The pressed and sintered molybdenum disc with a mass of $720 \mathrm{mg}$ dissolved under these conditions within 60 and $45 \mathrm{~min}$, respectively. A significantly longer time of dissolution of sintered molybdenum results from less porous structure and hence increasing hardness and mechanical strength after a high-temperature process carried out in a hydrogen atmosphere [31]. There are reported results of a higher dissolution rate of molybdenum sintered discs [35]. However, hydrogen peroxide of a higher concentration of $50 \%$ was used in such a case. The average processing times of $600 \mathrm{~g}$ molybdenum discs depended on the brand of hydrogen peroxide used, ranging from 140 to $255 \mathrm{~min}$.

The dissolution of molybdenum in inorganic acids was also reported [22, 41, 42]. However, molybdenum is insoluble in $\mathrm{HCl}, \mathrm{H}_{2} \mathrm{SO}_{4}, \mathrm{HF}, \mathrm{H}_{3} \mathrm{PO}_{4}$ and most other mineral acids, but it can be dissolved in $\mathrm{HNO}_{3}$ [43]. The dissolution is fast in diluted $\mathrm{HNO}_{3}$ and much slower in concentrated $\mathrm{HNO}_{3}$ due to the formation of inert oxide film on the metal surface, making it difficult to dissolve. Guro et al. [41] studied in detail the hydrogen peroxide oxidation of molybdenum and its subsequent dissolution in concentrated nitric and sulfuric acids. They demonstrated that the dissolution of metallic molybdenum in hydrogen peroxide is based on the phenomenon of corrosion and corrosion inhibition, and the oxidation of molybdenum and associated reduction of the hydrogen peroxide is accompanied by heterogeneous catalytic hydrogen peroxide decomposition and oxygen release. Gumiela et al. [42] dissolved metallic molybdenum powder and irradiated with protons pressed and sintered natural molybdenum disc in $3.5 \mathrm{M} \mathrm{HNO}_{3}$. Azarov et al. [22] proposed dissolving gram amounts of metallic molybdenum subjected to irradiation in the linear accelerator in a mixture of various inorganic acids resulting in obtaining soluble molybdenile salts. In such a way, they dissolved $30 \mathrm{~g}$ of molybdenum in the mixture of $53 \mathrm{ml}, 56 \%$ nitric acid, and $51 \mathrm{ml}, 40 \%$ hydrofluoric acid. Furthermore, researchers optimized the dissolution of $28.28 \mathrm{~g}$ of molybdenum in the mixture containing $54 \mathrm{ml}$ of nitric acid and $123 \mathrm{ml}$ of hydrochloric acid. The process lasted $2.5 \mathrm{~h}$.

Regardless whether the acidic or alkaline dissolution is used, it should be adapted to the subsequent separation of ${ }^{99 \mathrm{~m}} \mathrm{Tc}$ from the excess of molybdate. In order to selectively separate ${ }^{99 \mathrm{~m}} \mathrm{Tc}$ from the dissolved target material using the solid phase extraction chromatography, we wanted to use the resin selective for ${ }^{99 \mathrm{~m}} \mathrm{Tc}$ in the alkaline solution. In contrast to earlier published studies, in this work, we focused on the alkaline dissolution of pressed and sintered molybdenum target by electrochemical oxidation. The process was investigated and optimized towards complete and fast dissolution of molybdenum. To reach that goal, we explored whether external electromotive force (EMF) will shorten molybdenum dissolution time compared to chemical dissolution and if so, propose this method for dissolution of ${ }^{100}$ Mo irradiated target. The dissolution by electrochemical oxidation was compared with the conventional dissolution method.

Several possibilities of electrochemical dissolution of molybdenum were reported [44-47]. However, described techniques are not adapted to our purpose. The vast majority of scientific papers refer to anodizing molybdenum to obtain a molybdenum oxide as a functional coating protecting against corrosion [46-54]. The literature on the electrochemical, quantitative dissolution of molybdenum is scarce and limited to non-aqueous media $[48,55]$. In view of the above, the rapid, complete electrochemical dissolution of molybdenum is needed.

Molybdenum can be present in oxidation states from -2 to +6 . However, its most common oxidation state in aqueous solutions at room temperature is $+6[56,57]$. The molybdate species in aqueous solutions depend on the molybdenum concentration and the $\mathrm{pH}$. In neutral to mildly alkaline solutions, the monomeric $\mathrm{MoO}_{4}{ }^{2-}$ predominates. As the $\mathrm{pH}$ decreases, the anion becomes protonated, and the following molybdate species are formed:

$\mathrm{MoO}_{4}^{2-} \ldots>\mathrm{HMoO}_{4}^{-}>\mathrm{H}_{2} \mathrm{MoO}_{4}>\mathrm{HMoO}_{3}^{+}>\mathrm{MoO}_{2}^{2+}$

Molybdates tend to polymerize at higher molybdenum concentrations. At molybdenum concentrations above $10^{-3} \mathrm{~mol} \mathrm{Mo} / \mathrm{L}$ and $\mathrm{pH} 5-6$, the heptamolybdate ion is formed, and at $\mathrm{pH} 3-5$, octamolybdate predominates [56, 57].

Anodic dissolution of molybdenum depends mainly on the $\mathrm{pH}$ of the electrolyte [49]. The corrosion and passivation behavior of molybdenum in aqueous solutions at various $\mathrm{pH}$ was investigated using electrochemical impedance 
spectroscopy and potentiodynamic polarization. These studies revealed that molybdenum metal surface was always covered with a passive film, which was more stable in acidic solutions [50]. The activation energy of dissolution of the molybdenum oxide film was lower in alkaline solutions $(128.3 \mathrm{~kJ} / \mathrm{mol})$ than in neutral $(152.5 \mathrm{~kJ} / \mathrm{mol})$ or acidic solutions $(162.4 \mathrm{~kJ} / \mathrm{mol})$. This reflects the relative instability of the passive film in alkaline solutions, tending to metal dissolution.

The process of anodic dissolution of molybdenum in alkaline solution can be described by the following reactions (5)-(7) [46]:

$\mathrm{Mo}+2 \mathrm{OH}^{-} \rightarrow \mathrm{Mo}(\mathrm{OH})_{2}^{+}+3 \mathrm{e}$

$\mathrm{Mo}(\mathrm{OH})_{2}^{+}+\mathrm{OH}^{-} \rightarrow \mathrm{Mo}(\mathrm{OH})_{3}$

$\mathrm{Mo}(\mathrm{OH})_{3}+\mathrm{OH}^{-} \rightarrow \mathrm{MoO}_{4}^{2-}+4 \mathrm{H}_{2} \mathrm{O}+3 \mathrm{e}^{-}$

Molybdenum oxides layer formed on its surface during molybdenum anodic dissolution is continuously dissolved in alkaline solution. The efficiency of the process depends on the concentration of the solution [46]. The electrochemical potential and $\mathrm{pH}$ of the solution affect the exact ratio between different valence states. Therefore, in our experiments, we investigated the influence of parameters such as the concentration of the electrolyte solution, the addition of $30 \%$ hydrogen peroxide, temperature, current density, molybdenum mass and surface area of the platinum cathode on the dissolution rate of pressed and sintered molybdenum discs.

\section{Experimental}

\section{Materials and apparatus}

Molybdenum foil ( $0.1 \mathrm{~mm}$ thick, $99.9 \%$ pure) used in preliminary experiments on electrochemical dissolution was purchased from Goodfellow Cambridge Ltd., UK. Natural metal molybdenum powder ( $\geq 99.9 \%$ chemical purity) with a particle size of 1-2 $\mu \mathrm{m}$ in diameter used to prepare pressed and sintered discs was obtained from Sigma-Aldrich, Poland. Molybdenum discs with a density of $9.4 \mathrm{~g} / \mathrm{cm}^{3}$, a diameter of $12 \mathrm{~mm}$, and a thickness of $0.6 \mathrm{~mm}$ were manufactured by pressing molybdenum powder, followed by their sintering in hydrogen flow at a temperature of $1600{ }^{\circ} \mathrm{C}$ [31]. The mass of each molybdenum disc was $712 \pm 10 \mathrm{mg}(n=15)$ and corresponded to the mass of ${ }^{100}$ Mo target irradiated in cyclotron [34]. Platinum foil ( $0.1 \mathrm{~mm}$ thick, $99.9 \%$ pure) serving as a counter electrode (CE) and platinum mesh (99.9\% purity, nominal aperture: $0.12 \mathrm{~mm}$, wire diameter: $0.04 \mathrm{~mm}$, open area: 56\%) used as a counter electrode with a developed surface (CE) were obtained from Goodfellow Cambridge Ltd., UK. Lambda System (Poland) provided the $\mathrm{Hg} / \mathrm{HgO} 6 \mathrm{M}$ $\mathrm{KOH}$ reference electrode. Polyethylene foil doped with silica (Cookson Eutec, England) with pores diameter of $2 \div 4 \mu \mathrm{m}$ was used to separate cathodic and anodic chamber in an electrochemical cell. All used reagents were purchased with analytical grade from Sigma-Aldrich, Poland.

The Electrochemical Unit \& Impedance Analyzer ATLAS 0531, Atlas-Sollich, Poland, interfered with a PC was used for open-circuit voltage (OCV) measurements. Since the set ensured potential only up to $10 \mathrm{~V}$, to optimize parameters for yielded dissolution of molybdenum, the Programmable DC Power Supply, type PPS3210, Motech Industries Inc., Taiwan, assuring voltage up to $30 \mathrm{~V}$ was applied. The IKA RW 20 digital mixer (Germany) was used to mix electrolyte solutions.

\section{Electrochemical dissolution}

The electrochemical dissolution of molybdenum was performed by the galvanostatic method. To determine the current-voltage parameters of the investigated electrochemical systems, open-circuit voltage (OCV) measurements were performed. For this purpose, three electrodes system was used with molybdenum as the working electrode (WE), platinum foil as the counter electrode (CE), and mercury/mercury oxide $(\mathrm{Hg} / \mathrm{HgO} 6 \mathrm{M} \mathrm{KOH})$ reference electrode (RE).

The electrochemical setup (Fig. 1) consisted of two electrodes: small pieces $\left(1-5 \mathrm{~cm}^{2}\right)$ of molybdenum foil or molybdenum disc with a surface area of about $3 \mathrm{~cm}^{2}$ were

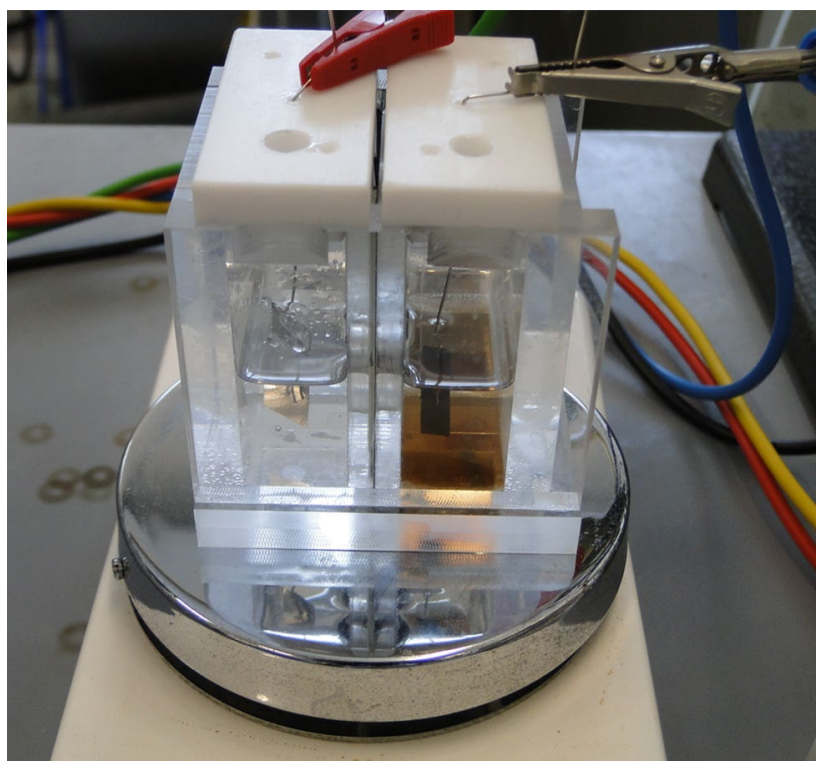

Fig. 1 Photograph of electrochemical setup used for molybdenum dissolution 
used as the anode. The dissolving Mo disc was wrapped in Pt mesh, forming a pocket for the disc. Electrical contact was ensured through this mesh hanging on Pt wire. Platinum foil $\left(3-21 \mathrm{~cm}^{2}\right)$ or mesh served as a cathode. Before each electrochemical process, electrodes in the form of foils were cleaned with a surfactant, rinsed with distilled water, degreased with ethanol, re-rinsed in distilled water, and finally dried for $30 \mathrm{~min}$ at $100{ }^{\circ} \mathrm{C}$. Due to the deposition of dissolved molybdenum on the opposite electrode, an electrochemical process was conducted in the vessel divided into two chambers by the separator made of polyethylene foil doped with silica. The catholyte and the anolyte solutions had the same composition and contained 1-5 M KOH. The selection of potassium hydroxide as electrolyte solution instead of more commonly used sodium hydroxide was justified by the greater solubility of molybdenum in the former one [58]. The volume of both catholyte and anolyte solutions was $13-20 \mathrm{ml}$. The anolyte solution was mixed during electrolysis with an overhead mixer at $\sim 500 \mathrm{rpm}$. The process was carried out at constant current density in the range of $14-280 \mathrm{~mA} / \mathrm{cm}^{2}$ for molybdenum foil and of $80-755 \mathrm{~mA} /$ $\mathrm{cm}^{2}$ for molybdenum sintered discs at ambient temperature and elevated to $55^{\circ} \mathrm{C}$. The effect of $30 \%$ hydrogen peroxide addition on the rate and the efficiency of electrochemical dissolution of molybdenum was investigated. To ensure the reliable effect of investigated parameters, all experiments were performed within $60 \mathrm{~min}$. This time limit was associated with the time needed for the chemical dissolution of pressed and sintered molybdenum [34]. Since this method allowed molybdenum to be completely dissolved in less than $60 \mathrm{~min}$, we assumed that our approach should provide no worse results. The efficiency of molybdenum dissolution was determined gravimetrically after drying the electrode.

Each experiment was repeated at least three times, and the presented curve and value describe the average result. Experiment errors were calculated using the commonly known standard deviation rule.

\section{Results and discussion}

\section{Open circuit voltage (OCV) measurements}

In order to assess the usefulness of the electrochemical cell for the dissolution of molybdenum, the voltage between two electrodes at an open-circuit voltage (OCV) was measured. The graph of voltage between molybdenum electrode $(2$ $\left.\mathrm{cm}^{2}, \mathrm{WE}\right)$ and platinum electrode $\left(3 \mathrm{~cm}^{2}, \mathrm{CE}\right)$ immersed in $\mathrm{KOH}$ solutions $(15 \mathrm{ml})$ of different concentrations is shown in Fig. 2. The negative values of registered voltage result from the way of electrodes connection: molybdenum electrode has lower standard potential $(-0.20 \mathrm{~V})$ than platinum electrode $(+1.2 \mathrm{~V})$, but since it is subjected for dissolution,

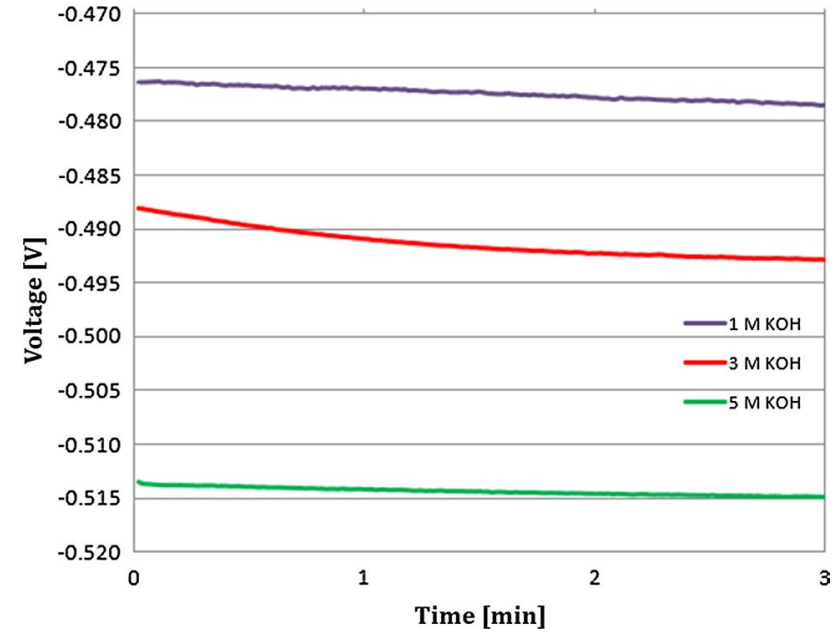

Fig. 2 Open circuit voltage (OCV) curves recorded for an electrochemical system containing molybdenum anode $\left(2 \mathrm{~cm}^{2}\right)$ and platinum cathode $\left(3 \mathrm{~cm}^{2}\right)$ immersed in $\mathrm{KOH}$ solutions $(15 \mathrm{ml})$ of various concentrations. The measurements performed at ambient temperature

it is connected as the working electrode. As depicted in Fig. 2, the voltage between these two electrodes increases with the increasing concentration of electrolyte solution. This is due to the increase of ionic conductivity in more concentrated $\mathrm{KOH}$ solutions. To verify a dominant oxidation state and type of chemical species formed by molybdenum in the investigated solution, molybdenum anode versus $\mathrm{Hg}$ / $\mathrm{HgO} 6 \mathrm{M} \mathrm{KOH}$ reference electrode potentials were measured. Recorded values were then recalculated to the potentials versus normal hydrogen electrode (NHE). The measurements were performed for the OCV system comprised of molybdenum foil $\left(1 \mathrm{~cm}^{2}\right)$ as a working electrode (WE) and $\mathrm{Hg} / \mathrm{HgO} 6 \mathrm{M} \mathrm{KOH}$ counter electrode (CE). The electrolyte was divided into two solutions: catholyte and anolyte solutions containing $13 \mathrm{ml}$ of $3 \mathrm{M} \mathrm{KOH}$ each. The measurements were conducted through a salt bridge saturated with $3 \mathrm{M} \mathrm{KOH}$. The exact measurements were repeated for the platinum electrode $\left(3 \mathrm{~cm}^{2}\right)$. The obtained results indicate that the potential of molybdenum and platinum electrodes versus $\mathrm{Hg} / \mathrm{HgO} 6 \mathrm{M} \mathrm{KOH}$ electrodes is accordingly $-0.443 \mathrm{~V}$ and $-0.045 \mathrm{~V}$, which after recalculation for NHE gives $-0.399 \mathrm{~V}$ and $0.089 \mathrm{~V}$, respectively. According to the Pourbaix diagram [56], for calculated potential and $\mathrm{pH}$ of 14 , the molybdenum half-cell exists in the area of $\mathrm{MoO}_{4}{ }^{2-}$, whereas platinum half-cell in the area of $\mathrm{Pt}_{\text {cryst }}$.

\section{Effect of current density}

The preliminary experiments of the electrochemical dissolution of molybdenum were performed for molybdenum foil with a lower mass of $60 \mathrm{mg}$. The effect of current density on voltage was investigated. The results obtained for dissolution 
of molybdenum anode $\left(60 \mathrm{mg}, 1 \mathrm{~cm}^{2}\right)$ in $13 \mathrm{ml} 3 \mathrm{M} \mathrm{KOH}$ are presented in Fig. 3. As was expected, the higher the current density, the greater the working electrochemical cell voltage.

Figure 4 illustrates the influence of current density on the dissolution of $60 \mathrm{mg}$ metal molybdenum in $3 \mathrm{M} \mathrm{KOH}$. The efficiency of molybdenum dissolution increases linearly with current density. It can be seen that at the current density of $15 \mathrm{~mA} / \mathrm{cm}^{2}$, only $15 \pm 2 \%(n=5)$ of molybdenum was dissolved. Increasing this parameter to $60 \mathrm{~mA} / \mathrm{cm}^{2}$ improved the yield to $56 \pm 3 \%(n=5)$, whereas almost all molybdenum, $99 \pm 1 \%(n=5)$, was dissolved when applying a current density of $100 \mathrm{~mA} / \mathrm{cm}^{2}$.

\section{Effect of initial molybdenum mass}

As expected, the rate and effectiveness of electrochemical dissolution were mass-dependent. When using the constant current of $100 \mathrm{~mA}$ and room temperature conditions, molybdenum anode with the mass of $60 \mathrm{mg}$ (Mo foil with a thickness of $0.1 \mathrm{~mm}$ ) entirely dissolved in $13 \mathrm{ml} 3 \mathrm{M} \mathrm{KOH}$ after $60 \mathrm{~min}$. Under the same conditions, the dissolving efficiency of pressed and sintered molybdenum disc with a mass of $712 \pm 10 \mathrm{mg}$ and thickness of $0.6 \mathrm{~mm}(n=15)$ reached only $23 \pm 1 \%(n=3)$. It is worth mentioning that not only molybdenum mass but also thickness of molybdenum anode can significantly affect dissolution rate. Considering two molybdenum discs of the same mass but different thicknesses, the surface of the one with the smaller thickness will be greater. The larger the metal surface, the greater the contact area of the metal with the solution, and thus the faster dissolution. This applies not only to chemical dissolution but also to electrochemical dissolution.

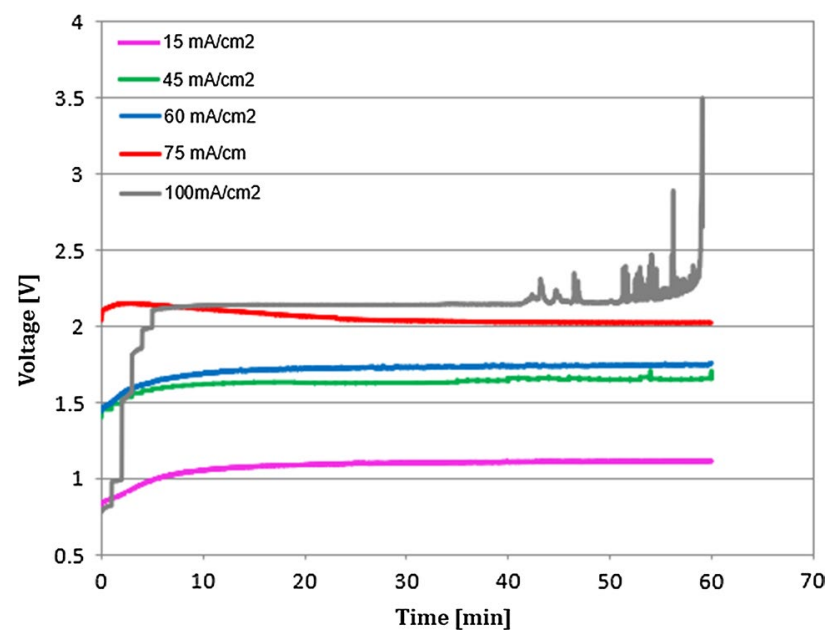

Fig. 3 Current density versus voltage in electrochemical cell containing molybdenum anode $\left(60 \mathrm{mg}, 1 \mathrm{~cm}^{2}\right)$ and platinum cathode $(3$ $\left.\mathrm{cm}^{2}\right)$. The measurements performed in $3 \mathrm{M} \mathrm{KOH}(13 \mathrm{ml})$ at ambient temperature

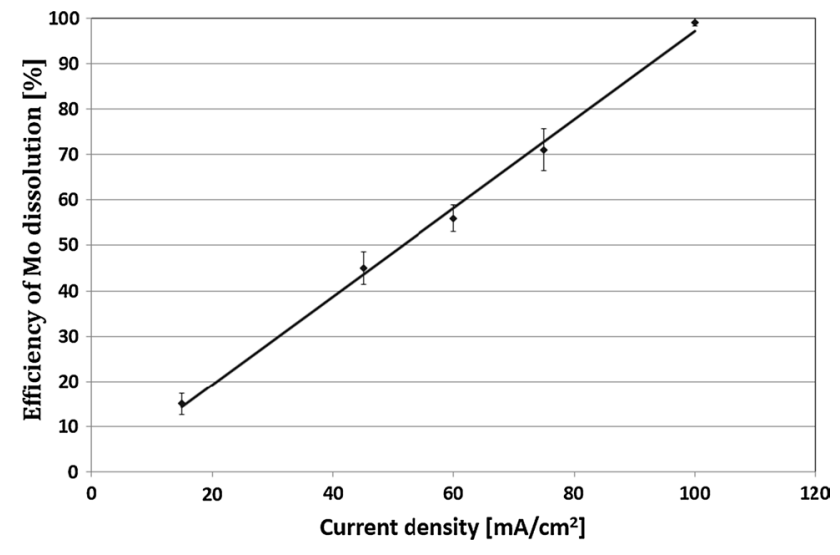

Fig. 4 Influence of current density on the efficiency of electrochemical dissolution of molybdenum foil $\left(60 \mathrm{mg}, 1 \mathrm{~cm}^{2}\right)$ in $13 \mathrm{ml}$ of $3 \mathrm{M}$ $\mathrm{KOH}$. The experiments were conducted versus platinum cathode ( 3 $\mathrm{cm}^{2}$ ) at ambient temperature

\section{Effect of platinum cathode surface area}

The attempts to improve the electrochemical dissolution of $712 \pm 10 \mathrm{mg}(n=15)$ pressed and sintered molybdenum disc by increasing platinum cathode surface area gave no satisfying results (Fig. 5). After increasing the platinum cathode surface area from 3 to $21 \mathrm{~cm}^{2}$, the yield of molybdenum dissolution remained at the same level of $23 \pm 2 \%$ $(n=4)$. Simultaneously, it was observed that the increase of the platinum surface area from $3 \mathrm{~cm}^{2}$ to $21 \mathrm{~cm}^{2}$ reduced voltage between the electrodes from $9.4 \pm 0.4 \mathrm{~V}(n=4)$ to $5.2 \pm 0.6 \mathrm{~V}(n=4)$, respectively. Replacement of platinum foil with a platinum mesh of the same size, hence increasing the surface of the platinum electrode, resulted in a further decrease of voltage to $3.3 \pm 0.4 \mathrm{~V}(n=4)$. This is an essential observation since while the increase in current density increases voltage (Fig. 3), the reduction of

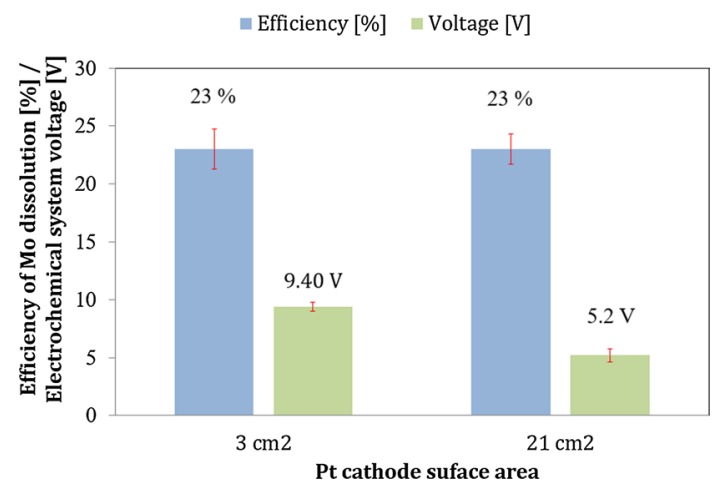

Fig. 5 Influence of platinum cathode surface area on the efficiency of electrochemical dissolution of molybdenum with the mass of $712 \pm 10 \mathrm{mg}(n=15)$ in $3 \mathrm{M} \mathrm{KOH}$. The experiments were performed at a current density of $100 \mathrm{~mA} / \mathrm{cm}^{2}$ at ambient temperature 
the voltage with the extension of platinum cathode dimensions allows to use higher current densities, resulting in increased rate and efficiency of molybdenum dissolution (Fig. 4).

\section{Effect of potassium hydroxide concentration}

Figure 6 illustrates the effect of potassium hydroxide concentration of 1,3 , and $5 \mathrm{~mol} / \mathrm{dm}^{3}$ on the electrochemical dissolution of molybdenum at room temperature and current density of $285 \mathrm{~mA} / \mathrm{cm}^{2}$. In $1 \mathrm{M} \mathrm{KOH}$, molybdenum did not dissolve. The yield of dissolution increased with the concentration of $\mathrm{KOH}$ and reached $23 \pm 2 \%(n=4)$ for $3 \mathrm{M} \mathrm{KOH}$ and $37 \pm 2 \%(n=4)$ for $5 \mathrm{M} \mathrm{KOH}$. However, particulates dark brown-colored of a near colloidal nature came off the anode.

\section{Effect of hydrogen peroxide addition}

It was found that the addition of $1 \mathrm{ml}$ of $30 \%$ hydrogen peroxide per $20 \mathrm{ml}$ of alkaline electrolyte solution increased the yield of molybdenum dissolution. This effect improves with the increase of $\mathrm{KOH}$ concentration. As shown in Fig. 7, the efficiency of molybdenum dissolution in electrolytes containing $1 \mathrm{M}, 3 \mathrm{M}$, and $5 \mathrm{M} \mathrm{KOH}$ doped with $1 \mathrm{ml}$ of $30 \%$ hydrogen peroxide achieved $22 \pm 3 \%(n=4)$, $62 \pm 3 \%(n=4)$ and $72 \pm 3 \%(n=4)$, respectively. However, when the volume of $30 \%$ hydrogen peroxide was increased to $2 \mathrm{ml}$, the electrochemical dissolution yield decreased to $38 \pm 2 \%(n=4)$. This effect is illustrated in Fig. 8 .

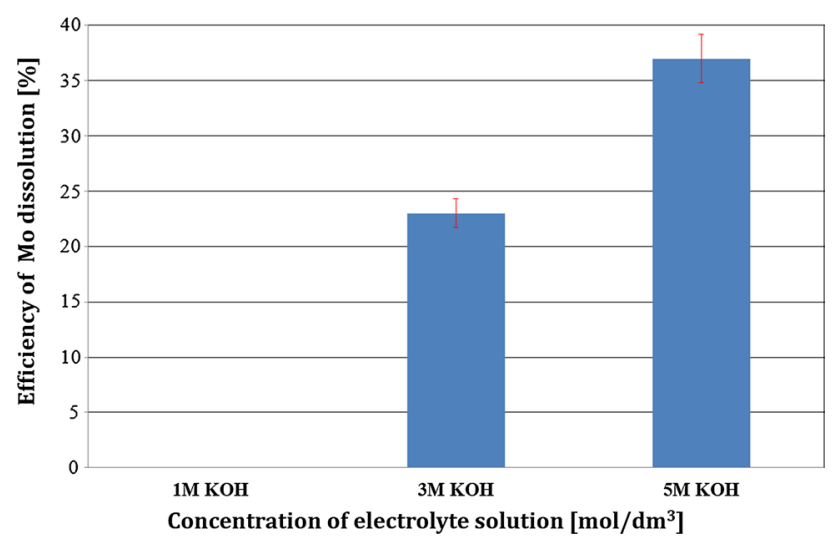

Fig. 6 Influence of potassium hydroxide concentration on the efficiency of electrochemical dissolution of molybdenum. The measurements recorded for dissolution of $712 \pm 10 \mathrm{mg}(n=15)$ pressed and sintered molybdenum discs at a current density of $285 \mathrm{~mA} / \mathrm{cm}^{2}$ and ambient temperature. The volume of the electrolyte solution was $20 \mathrm{ml}$

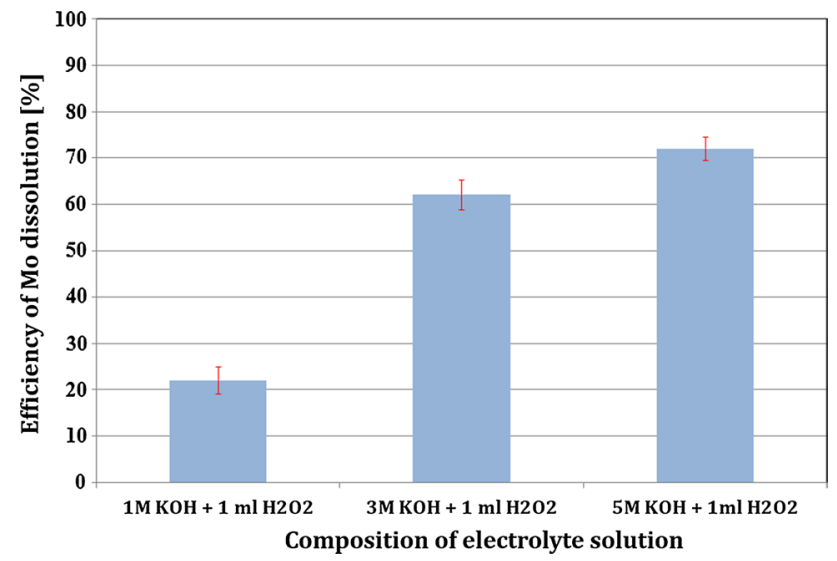

Fig. 7 Effect of $30 \%$ hydrogen peroxide addition to $\mathrm{KOH}$ solutions of various concentrations on the efficiency of electrochemical dissolution of $712 \pm 10 \mathrm{mg}(n=15)$ pressed and sintered molybdenum discs. The experiments performed versus $21 \mathrm{~cm}^{2}$ platinum cathode, at a current density of $480 \mathrm{~mA} / \mathrm{cm}^{2}$, at ambient temperature

\section{Effect of temperature}

At an elevated temperature of $55{ }^{\circ} \mathrm{C}$, the molybdenum electrochemical dissolution yield in $5 \mathrm{M} \mathrm{KOH}$ increased from $37 \pm 2 \%(n=4)$ to $80 \pm 3 \%(n=4)$. Such results were obtained when attempting to dissolve $712 \pm 10 \mathrm{mg}$ $(n=15)$ molybdenum sintered discs at the current density of $100 \mathrm{~mA} / \mathrm{cm}^{2}$. However, at temperatures higher than $55^{\circ} \mathrm{C}$, foaming of the electrolyte and leaps of the voltage between electrodes were observed.

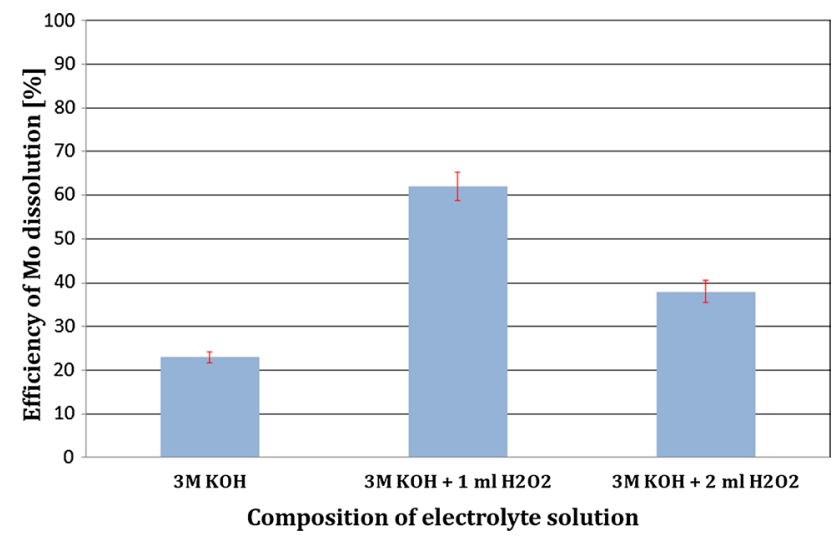

Fig. 8 Influence of hydrogen peroxide concentration in electrolyte solution on the efficiency of electrochemical dissolution of $712 \pm 10 \mathrm{mg}(n=15)$ pressed and sintered molybdenum disc. The experiments performed versus $21 \mathrm{~cm}^{2}$ platinum cathode, at a current density of $480 \mathrm{~mA} / \mathrm{cm}^{2}$, at ambient temperature 
Table 1 Influence of current density on the time of complete dissolution of pressed and sintered molybdenum discs

\begin{tabular}{lll}
\hline $\begin{array}{l}\text { Mass of Mo discs } \\
(\mathrm{mg})\end{array}$ & $\begin{array}{l}\text { Current density }(\mathrm{mA} / \\
\left.\mathrm{cm}^{2}\right)\end{array}$ & $\begin{array}{l}\text { Time of complete } \\
\text { dissolution }(\mathrm{min})\end{array}$ \\
\hline 716 & 285 & $95 \pm 2$ \\
722 & 335 & $74 \pm 3$ \\
714 & 365 & $69 \pm 1$ \\
722 & 400 & $83 \pm 2$ \\
722 & 435 & $85 \pm 2$ \\
\hline
\end{tabular}

The values are given as mean $\pm \mathrm{SD}, n=4$

\section{Determination of complete dissolution rate}

In summary, the electrochemical dissolution of molybdenum was most efficient in $5 \mathrm{M} \mathrm{KOH}$. The yield of $80 \pm 3 \%(n=4)$ was achieved in $5 \mathrm{M} \mathrm{KOH}$ solution at an elevated temperature of $55{ }^{\circ} \mathrm{C}$, whereas at ambient temperature, the highest yield of $72 \pm 3 \%(n=4)$ was reached for the mixture of $5 \mathrm{M}$ $\mathrm{KOH}$ and $30 \%$ hydrogen peroxide. In order to reduce the time needed for the complete dissolution of molybdenum anode, the influence of current density on dissolution rate was studied. Results are given in Table 1. It can be seen that the rate of dissolution of pressed and sintered molybdenum disc raised with increasing current density from 283 to $367 \mathrm{~mA} / \mathrm{cm}^{2}$. Time required for complete dissolution in this range of current density decreased from $95 \pm 2 \min (n=4)$ to $69 \pm 1 \mathrm{~min}(n=4)$. Further increase of current density led to a slower dissolution rate. The shortest time required for complete electrochemical dissolution of sintered molybdenum disc with a mass of $712 \pm 10 \mathrm{mg}(n=15)$ was about $70 \mathrm{~min}$. As a result, a yellowish, clear solution was obtained. This color is most likely from the presence of molybdic acid (hydrated forms of molybdenum trioxide and related species) forming monohydrates $\mathrm{MoO}_{3} \cdot \mathrm{H}_{2} \mathrm{O}$ and dihydrates $\mathrm{MoO}_{3} \cdot 2 \mathrm{H}_{2} \mathrm{O}$. For further dissolution, after the electrochemical process, $2 \mathrm{ml}$ of $30 \%$ hydrogen peroxide were added, and the yellow color disappeared.

\section{Conclusions}

This work presents the results of the electrochemical dissolution of pressed and sintered molybdenum discs, typically serving as targets for cyclotron production of ${ }^{99 \mathrm{~m}} \mathrm{Tc}$ [31]. The shortest time for total dissolution of molybdenum target $712 \pm 10 \mathrm{mg}(n=15)$ in mass was $70 \mathrm{~min}$. This result was obtained using an electrolyte solution of $5 \mathrm{M} \mathrm{KOH}$, temperature $55^{\circ} \mathrm{C}$, and the current density of $365 \mathrm{~mA} / \mathrm{cm}^{2}$. For complete dissolution of molybdenum, resulting in the formation of a colorless solution, the addition of $30 \%$ hydrogen peroxide was needed. These results are comparable to the chemical dissolution method. The lower temperature used in electrochemical dissolution $\left(55^{\circ} \mathrm{C}\right.$ vs. $90^{\circ} \mathrm{C}$ in the chemical dissolution method) is easier to control. In the chemical process, high concentrations of reagents are used (oxidation of molybdenum by $30 \%$ or even $50 \%$ hydrogen peroxide as the first step of dissolution), the reaction is turbulent, exothermic, and the oxygen is released. For these reasons, the process of chemical dissolution of molybdenum must be monitored, and reagents should be added in portions. From that point of view, the electrochemical dissolution of molybdenum allows remote control by adjusting the current-voltage conditions. The method can be easily adopted for hot-cell operation and for automation. Nevertheless, the final choice of the method used for the dissolution of the molybdenum target will depend on a particular user. This work may help in making a choice giving closer insight into the electrochemical process.

Acknowledgements This work was supported with the funds awarded by the Ministry of Science and Higher Education in Poland within the agreement No. 3969/IAEA/2018/0, IAEA Research Contract No. 22652, and CERAD project, financed under Smart Growth Operational Programme 2014-2020, Priority IV, Measure 4.2.

Open Access This article is licensed under a Creative Commons Attribution 4.0 International License, which permits use, sharing, adaptation, distribution and reproduction in any medium or format, as long as you give appropriate credit to the original author(s) and the source, provide a link to the Creative Commons licence, and indicate if changes were made. The images or other third party material in this article are included in the article's Creative Commons licence, unless indicated otherwise in a credit line to the material. If material is not included in the article's Creative Commons licence and your intended use is not permitted by statutory regulation or exceeds the permitted use, you will need to obtain permission directly from the copyright holder. To view a copy of this licence, visit http://creativecommons.org/licenses/by/4.0/.

\section{References}

1. The NEA (2018) The Supply of Medical Radioisotopes. Medical Isotope Demand and Capacity Projection for the 2018-2023 Period, OECD Nuclear Energy Agency, Paris, France

2. The IAEA (2015) Feasibility of Producing Molybdenum-99 on a Small Scale Using Fission of Low Enriched Uranium or Neutron Activation of Natural Molybdenum. Technical Reports Series 478, Austria, Vienna

3. The NEA (2010) The Supply of Medical Radioisotopes. Review of Potential Molybdenum-99/Technetium-99m Production Technologies. OECD, Paris, France

4. Tollesfon J (2016) Reactor shutdown threatens world's medical isotope supply. Earth Clim. https://doi.org/10.1038/nature.2016. 20577

5. Pillai MR, Knapp FF Jr (2011) Overcoming the ${ }^{99 \mathrm{~m}} \mathrm{Tc}$ shortage: are options being overlooked? J Nuc Med 52(2): $15 \mathrm{~N}-16 \mathrm{~N}, 28 \mathrm{~N}$

6. Ballinger R (2010) Mo-99 shortage in nuclear medicine: crisis or challenge? J Label Compd Radiopharm 53:167-168

7. Naik H, Suryanarayana SV, Jagadeesan KC, Thakare SV, Joshi PV, Nimje VT, Mittal KC, Goswami A, Venugopal V, Kailas S (2013) 
An alternative route for the preparation of the medical isotope ${ }^{99}$ Mo from the ${ }^{238} \mathrm{U}(\gamma, \mathrm{f})$ and ${ }^{100} \mathrm{Mo}(\gamma, \mathrm{n})$ reactions. J Radioanal Nucl Chem 295:805-816

8. Van Do N, Khue PD, Thien Than K, Van Loat B, Rahman MS, Kim KS, Oh Y, Lee HS (2009) Thermal neutron cross-section and resonance integral of the ${ }^{98} \mathrm{Mo}\left(\mathrm{n}, \gamma{ }^{9} 9 \mathrm{Mo}\right.$ reaction. Nucl Instrum Methods Phys Res B 267:462-468

9. Chattopadhyay S, Sujata SD, Das M, Goomer NC (2008) Recovery of ${ }^{99 \mathrm{~m}} \mathrm{Tc}$ from $\mathrm{Na}_{2}\left[{ }^{99} \mathrm{Mo}\right] \mathrm{MoO}_{4}$ solution obtained from reactor-produced (n, $\gamma^{9} 9$ Mo using a tiny Dowex-1 column in tandem with a small alumina column. Appl Rad Isot 66:1814-1817

10. Tsuchiya K, Mutalib A, Chakrov P, Kaminaga M, Ishihara M, Kawamura H (2012) Status of ${ }^{99} \mathrm{Mo}^{-99 \mathrm{~m}} \mathrm{Tc}$ Production Development by $(\mathrm{n}, \gamma)$ reaction. In: Proceeding of the 4th International symposium in material Testing Reactors JAEA-Conf 2011-003, pp 137-141

11. The IAEA (2017) Cyclotron Based Production of Technetium99m. IAEA, Vienna, ISBN 978-92-0-102916-4

12. Stichelbaut F, Jongen Y (2011) Design of accelerator-based solutions to produce Mo-99 using lowly-enriched uranium. Prog Nucl Sci Technol 2:284-288

13. Guérin B, Tremblay S, Rodrigue S, Rousseau JA, Dumulon-Perreault V, Lecomte R, van Lier JE, Zyuzin A, van Lier EJ (2010) Cyclotron production of ${ }^{99 \mathrm{~m}} \mathrm{Tc}$ : an approach to the medical isotope crisis. J Nucl Med 51:13N

14. Beaver JE, Hupf HB (1971) Production of Tc-99m on a medical cyclotron: a feasibility study. J Nucl Med 12:739-741

15. Martini P, Boschi A, Cicoria G, Zagni F, Corazza A, Uccelli L, Pasquali M, Pupillo G, Marengo M, Loriggiola M, Skliarova H, Mou L, Cisternino S, Carturan S, Melendez-Alafort L, Uzunov NM, Bello M, Alvarez CR, Esposito J, Duatti A (2018) In-house cyclotron production of high-purity Tc-99m and Tc-99m radiopharmaceuticals. Appl Rad Isot 139:325-331

16. Schaffer P, Bénard F, Bernstein A, Buckley K, Celler A, Cockburn N, Corsaut J, Dodd M, Economou C, Eriksson T, Frontera M, Hanemaayer V, Hook B, Klug J, Kovacs M, Prato FS, McDiarmid S, Ruth TJ, Shanks C, Valliant JF, Zeisler S, Zetterberg U, Zavodszky PA (2015) Direct Production of ${ }^{99 \mathrm{~m}} \mathrm{Tc}$ via ${ }^{100} \mathrm{Mo}(\mathrm{p}, 2 \mathrm{n})$ on small Medical Cyclotrons. Phys Procedia 66:383-395

17. Bénard F, Buckley KR, Ruth TJ, Zeisler SK, Klug J, Hanemaayer V, Vuckovic M, Hou X, Celler A, Appiah J, Valliant J, Kovacs MS, Schaffer P (2014) Implementation of multi-curie production of ${ }^{99 \mathrm{~m}} \mathrm{Tc}$ by conventional medical cyclotrons. J Nucl Med 55:1017-1022

18. Richards VN, Mebrahtu E, Lapi SE (2013) Cyclotron production of ${ }^{99 \mathrm{~m}} \mathrm{Tc}$ using ${ }^{100} \mathrm{Mo}_{2} \mathrm{C}$ targets. Nucl Med Biol 40:939-945

19. Targholizadeh H, Raisali G, Jalilian AR, Rostampour N, Ensaf M, Dehghan MK (2010) Cyclotron production of technetium radionuclides using a natural metallic molybdenum thick target and consequent preparation of [Tc]-BRIDA as a radio-labelled kit sample. Nukleonika 55:113-118

20. Stevenson NR (2011) Technetium-99m produced by proton irradiation of a fluid target system. Patent US 20110280357

21. Starovoitova VN, Tchelidze L, Wells DP (2014) Production of medical radioisotopes with linear accelerators. Appl Radiat Isot 85:39-44

22. Azarov AI, Bocharov VA, Dolzhek MA et al (2014) Production of technetium in molybdenum target on linac and modeling technetium distillation. Voprosy Atomnoj Nauki i Tekhniki, Probl Atomic Sci Technol Ser Nucl Phys A 63:59-62

23. Zawistowski T, Wronka S (2021) Simulation of ${ }^{99}$ Mo production from $30 \mathrm{MeV}$ electron linear accelerator. Acta Phys Pol A No 4:451-453. https://doi.org/10.12693/APhysPolA.139.451

24. Mang'era K, Ogbomo K, Zriba R, Fitzpatrick J, Brown J, Pellerin E, Barnard J, Saunders Ch, de Jong M (2015) Processing and evaluation of linear accelerator-produced $99 \mathrm{Mo} / 99 \mathrm{mTc}$ in Canada. J Radioanal Nucl Chem 305:79-85

25. Mang'era K, Alina M, Barnard J, Omotayo A, Brown P, Martin J, Carlson P, Saunders C, Hayward P (2011) Production, separation and evaluation of Tc-99m and Mo-99 from accelerator transmutation of Mo-100. J Nucl Med 52(Suppl 1):1439

26. Bennet RG, Terry WK, Christian JD, Kirkham RJ, Petti DW (1999) A system of ${ }^{99 \mathrm{~m}} \mathrm{Tc}$ production based on distributed electron accelerators and thermal separation. Nucl Technol 126:102-121

27. Bertsche K (2010) Accelerator Production Options for Mo-99. SLAC National Accelerator Laboratory (SLAC)

28. Danon Y, Block R, Harvey J (2010) Production of Mo-99 using $30-\mathrm{MeV}$ electrons and a Mo-100 target. Trans Am Nucl Soc 103:1081-1082

29. Gagnon K, McQuarrie S, Wilson J (2012) Production of technetium from a molybdenum metal target. Patent WO 2012139220A1

30. Stolarz A, Kowalska JA, Jasiński P, Janiak T, Samorajczyk J (2015) Molybdenum targets producted by mechanical reshaping. J Radioanal Nucl Chem 305:947-952

31. Cieszykowska I, Janiak T, Barcikowski T, Mielcarski M, Mikołajczak R, Choiński J, Barlak M, Kurpaska Ł (2017) Manufacturing and characterization of molybdenum pellets used as targets for ${ }^{99 \mathrm{~m}} \mathrm{Tc}$ production in cyclotron. Appl Rad Isot 124:124-131

32. Skliarova H, Cisternino S, Cicoria G, Marengo M, Palmieri V (2019) Innovative target for production of Technetium-99m by biomedical cyclotron. Molecules 24:25

33. Hanemaayer V, Zeislera SK, Buckleya KR, Kluga J, Kovacsb M, Bérnardb F, Rutha TJ, Schaffer P (2012) Solid targets for ${ }^{99 \mathrm{~m}} \mathrm{Tc}$ production on medical cyclotrons. In: 14th international workshop on targetry and target chemistry, AIP Conf Proc 1509:120-124

34. Pawlak DW, Wojdowska W, Parus LJ, Mikołajczak R (2016) Application of Ana Lig resin for ${ }^{99 \mathrm{~m}} \mathrm{Tc}$ separation from ${ }^{100} \mathrm{Mo}$ target irradiated in cyclotron. App Radiat Isot 113:75-78

35. Tkac P, Rotsch DA, Chemerisov SD, Byrnes JP, Bailey JL, Wiedmeyer SG (2021) Large-scale dissolution of sintered Mo disks. J Radioanal Nucl Chem 327:617-626

36. Tkac P, Vandegrift GF, Harvey J (2012) Dissolution of Sintered Mo Disks. Argonne National Laboratory: Report ANL/CSE$13 / 1911$

37. Tkac P, Vandegrift GF, Nunn S, Harvey J (2013) Processing of sintered Mo disks using hydrogen peroxide. Argonne National Laboratory Report ANL/CSE-13/44 12

38. Tkac P, Vandegrift GF (2014) Dissolution of sintered Mo disks. Argonne National Laboratory Report ANL/CSE-14/26 13

39. Tkac P, Rotsch DA, Stepinski D, Makarashvili V, Vandegrift GF, Harvey J (2016) Optimization of the processing of Mo disks. Argonne National Laboratory Report ANL/NE-15/46 14

40. Tkac P, Rotsch DA, Chemerisov SD, Bailey JL, Krebs JF, Vandergrift GF (2016) Optimization of the dissolution of molybdenum disks: FY-16 results. Argonne National Laboratory Report ANL/ NE-16/28

41. Guro VP (2008) Molybdenum dissolution in mixtures of $\mathrm{H}_{2} \mathrm{O}_{2}$ and concentrated $\mathrm{HNO}_{3}$ and $\mathrm{H}_{2} \mathrm{SO}_{4}$ in the presence of tungsten. Inorg Mater 44:239-243

42. Gumiela M, Dudek J, Bilewicz A (2016) New precipitation method for isolation of ${ }^{99 \mathrm{~m}} \mathrm{Tc}$ from irradiated ${ }^{100}$ Mo target. J Radioanal Nucl Chem 310:1061-1067. https://doi.org/10.1007/ s10967-016-4967-2

43. Patnaik P (2003) Handbook of inorganic chemicals. The McGrawHill Companies, New York, ISBN 0-07-049439-8

44. Abbas Q, Binder L (2011) The electrochemical dissolution of molybdenum in non-aqueous media. Int $\mathbf{J}$ Refract Hard 29:542-546 
45. Csanyi LJ, Horvath I, Galbacs ZM (1989) Peroxide derivatives of molybdenum (VI) in neutral and alkaline media. Transit Met Chem 14:90-94

46. Hull MN (1972) On the anodic dissolution of molybdenum in acidic and alkaline electrolytes. J Electroanal Chem Int Electrochem 38:143-157

47. Petrova M, Bojinov M (2009) A mechanism of anodic dissolution of molybdenum in weakly acidic and neutral electrolytes. J Univ Chem Technol Metall 44:286-290

48. Abd El-Rahman HA, Gad-Allah AG, Abou-Romia MM (1987) Anodization of molybdenum II. Electrical breakdown. J Appl Electrochem 17:899-904

49. Badawy WA, Gad-Allah AG, Abd El-Rahman HA, Abouromia MM (1966) Kinetics of the passivation of molybdenum in acids and alkali solutions as inferred from impedance and potential measurements. Surf Coat Technol 27:187-196

50. Badawy WA, Al-Kharafi FM (1997) Electrochemical behavior of molybdenum in aqueous solutions. Bull Electrochem 13:392-398

51. Badawy WA, Al-Kharafi FM (1998) Corrosion and passivation behaviors of molybdenum in aqueous solutions of different $\mathrm{pH}$. Electrochim Acta 44:693-702

52. Gad-Allah AG, Abd El-Rahman HA (1987) Anodization of molybdenum. I. Galvanostatic anodization. J App Electrochem 17:1065-1074
53. Wang K, Li YS, He P (1998) In situ identification of surface species on molybdenum in different media. Electrochim Acta 43:2459-2467

54. Wilkstrom LL, Nobe K (1969) The Electrochemical Behavior of Molybdenum. J Electrochem Soc 116:525-530

55. Kuznietz M, Cotler C (1988) Progressive dissolution of molybdenum foils in liquid uranium at $1160^{\circ} \mathrm{C}$. J Nucl Mater 160(2-3):196-200

56. Ciszewski A, Baraniak M (2006) Chemical and electrochemical activity of the elements in the environment of water, Poznan University of Technology Publisher In Polish

57. Saji VS, Lee ChW (2012) Molybdenum, molybdenum oxides, and their electrochemistry. Chem Sus Chem 5:1146-1161

58. Tkac P, Vandergrift GF (2016) Recycle of enriched Mo targets for economic production of ${ }^{99} \mathrm{Mo} /{ }^{99 \mathrm{~m}} \mathrm{Tc}$ medical isotope without use of enriched uranium. J Radioanal Nucl Chem 308:205-212

Publisher's Note Springer Nature remains neutral with regard to jurisdictional claims in published maps and institutional affiliations. 